\title{
The accelerating effects of the microorganisms on biodeterioration of stone monuments under air pollution and continental-cold climatic conditions in Erzurum, Turkey
}

\author{
Y. Nuhoglu ${ }^{\text {a,* }}$, E. Oguz ${ }^{\text {a }}$, H. Uslu ${ }^{\text {b }}$, A. Ozbek ${ }^{\text {b }}$, B. Ipekoglu ${ }^{\text {c }}$, I. Ocak ${ }^{\text {, }}$, \\ I. Hasenekoglu ${ }^{\mathrm{d}}$ \\ a Atatürk University, Department of Environmental Engineering, Engineering Faculty, 25240, Erzurum, Turkey \\ b Atatürk University, Department of Clinical Microbiology, Medicine Faculty, 25240, Erzurum, Turkey \\ ${ }^{\mathrm{c}}$ Izmir Institute of Technology, Faculty of Architecture, Department of Architectural Restoration 35430, Izmir, Turkey \\ d Atatürk University, Department of Biology, K.K Education Faculty, 25240 Erzurum, Turkey
}

Received 9 March 2005; accepted 16 June 2005

Available online 18 October 2005

\begin{abstract}
The aim of this research was to determine the accelerating effects of microorganisms on the biodeterioration of stone under air pollution and continental-cold climatic region in Erzurum, Turkey.

Studies have been carried out on specimens of the Rustempasa Bazaar, the Lalapasa Mosque, the Erzurum Castle Mosque, the Double Minarets-Madrasah, the Great Mosque and the Haji Mehmet Fountain aged from 441 to 823 years old. The results showed that vegetative and reproductive (generative) forms of the microorganisms could develop during the winter months when the night time average temperature was even $-25^{\circ} \mathrm{C}$. Also the reproductive forms had developed and the whole stone surface was covered with a biofilm caused by the microorganisms. Silicon, aluminum, calcium, potassium, titanium, magnesium, zinc, sulfur, iron, sodium, and niobium were found in the stones of the historical buildings with varying amounts through the SEM-EDS analysis. Some of these elements could be used as an energy resource for the microorganisms together with the air pollutants such as sulfur dioxide, nitrogen oxides and particles on the stone surfaces. Of 21 isolates, 15 species from 6 bacterium genera and 5 species from 5 fungi genera plus 1 fungi genera were identified on the deteriorated stone surfaces even during the coldest months by microbial identification system (MIS) and these findings were tested by SEM investigations. (C) 2005 Elsevier B.V. All rights reserved.
\end{abstract}

Keywords: Stone monuments; Biodeterioration; Continental-cold climate

\section{Introduction}

* Corresponding author. Fax: +90 4422360957.

E-mail address: ynuhoglu@atauni.edu.tr (Y. Nuhoglu).
Stone has been one of the most intensely studied materials in conservation. The problem of understanding the deterioration of stone is compounded by the 
large range of types with different mineralogical and physical characteristics and their varying weathering responses under different climatic and environmental conditions (Kumar and Kumar, 1999). Many agents such as physical, chemical and biological contribute to the deterioration of stone monuments, buildings, and other objects of cultural value. Degradation of stone materials under permanently open air conditions is mainly controlled by interacting chemical and mechanical processes leading to the destruction of the microstructure by the degradation processes and the propagation of micro-cracks. Degradation processes is considerably affected by the accumulation of damage resulting from time variant external loading in conjunction with environmentally induced mechanisms such as moisture and heat transport, freeze-thaw actions, chemically expansive reactions, shrinkage and chemical dissolution or by the corrosion of the reinforcement. Physical, chemical and biological agents act together, ranging from synergistic to antagonistic, in the deterioration of stone. A considerable number of investigations have begun to examine the essential role biological agents play in the deterioration of stone (Warscheid and Braams, 2000).

Biodeterioration may be defined as any undesirable change in the properties of a material caused by the vital activities of living organisms. This definition distinguishes biodeterioration from fields of study such as corrosion and wear of materials that relate to undesirable changes in the properties of a material brought about by chemical, mechanical, and physical influences. The development of specific biological species on a particular stone surface is determined by the nature and properties of the stone (mineral constituents, $\mathrm{pH}$, relative percentage of various minerals, salinity, moisture content, texture). It also depends on certain environmental factors (temperature, relative humidity, light conditions, atmospheric pollution levels, wind, rainfall). In other words, the response of living organisms to a potentially colonizable surface depends on the ecological and physiological requirements of the biological species involved (Kumar and Kumar, 1999).

Mankind contributes to the biodeterioration of exposed stone materials as a destroyer of natural balance. Air pollution resulting from anthropogenic sources such as electric utilities, domestic heating and transportation have increased the atmospheric pollu- tants and their deposition on stone surfaces. The complex physical and chemical interactions of atmospheric pollutants with the mineral material have accelerated the decay of stones (Warscheid and Braams, 2000; Zanardini et al., 2000; Tecer and Cerit, 2002). Microbiological deterioration, caused by microorganisms growing on the material surfaces, follows the chemical deterioration (Zanardini et al., 2000). Biodeterioration has usually been considered to be a degradation process following the initial deteriorating effects of inorganic agents. These agents were thought to condition stone surfaces for microbial contamination due to structural changes and the enrichment of inorganic and organic nutrient substrates. The microorganisms present on external stone walls of building are fungi, bacteria (including actinomycetes), algae (including cyanobacteria), lichens and protozoa (Warscheid and Braams, 2000; Zanardini et al., 2000; Tomaselli et al., 2000).

Algae and cyanobacteria are usually the first colonizers of historical monuments due to their photosynthetic nature. These microorganisms can deteriorate stone either chemically or mechanically and their presence is generally detected through the formation of patina or crusts. Lichens, which are highly resistant to desiccation and extreme temperatures, are also frequently associated with biodeterioration of stone, as are mosses and vascular plants. Autotrophic and heterotrophic bacteria present in biofilms cause stone decay by physical and chemical effects. Finally, once established on the substratum fungi also cause deterioration of stone by chemical or mechanical effects (Herrera et al., 2004).

Microorganisms are able to obtain different elements for their metabolism, e.g., calcium, aluminum, silicon, iron and potassium, by biosolubilization of materials. Such microbial biosolubilization involves the production of organic and inorganic acids by the metabolic activity of algae, lichens, fungi and bacteria. This acidic deterioration is one of the best known biogeochemical mechanisms of rock decay (Herrera et al., 2004).

Until recently, biodeteriorative colonisers of the stone materials were considered to be autotrophic microorganisms, capable of surviving on inorganic substrates, because of their capacity to utilise $\mathrm{CO}_{2}$, and it was considered that the heterotrophics could colonise the stone substrates only later, in accordance 


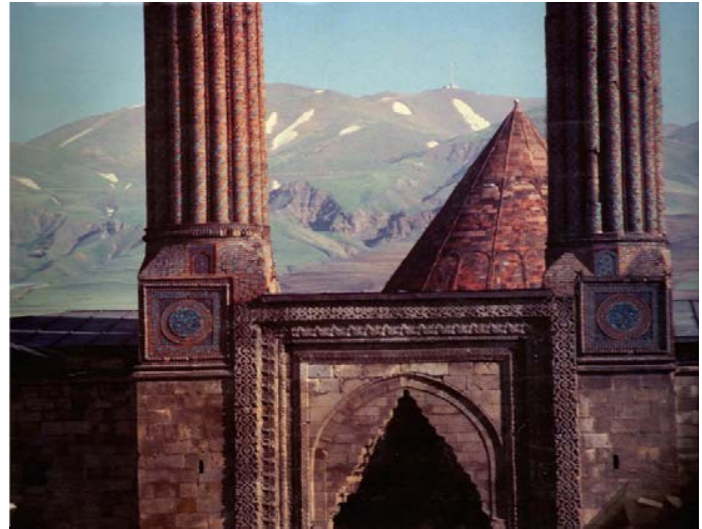

Fig. 1. The Double Minarets-Madrasah.

to a real ecological succession, utilising the organic substances released by the cellular lysis of the autotrophics (Zanardini et al., 2000). The recent researches demonstrated that numerous heterotrophic microorganisms present on the stonework can utilize, for their growth, the airborne organic compounds settled on the stone surface. They mainly arise from the incomplete combustion of fossil fuels (Saiz-Jimenez, 1997; Zanardini et al., 2000). This evidence indicates that heterotrophic microorganisms can act as first colonizers in the areas with a high level of organic pollutants (Zanardini et al., 2000).

Although the biodeterioration of stone monuments in tropical regions due to the action of biodeteriogens has long been recognized, biodeterioration in continental-cold climatic region has not been perfectly understand up to now. We think that this research give information to understanding of this subject. The aim of this research was to determine the accelerating effects of the microorganisms on the biodeterioration of stone under the air pollution and continental-cold climatic region in Erzurum, Turkey.

\section{Materials and methods}

\subsection{The characteristics of Erzurum}

Erzurum is on a plateau surrounded by mountains (Fig. 1). The height of this plateau is around $2000 \mathrm{~m}$. The population of Erzurum is 366,000 . Topographic structure and geographic location cause a hard steppe climate around the city. It is located at $39^{\circ} 55^{\prime} \mathrm{N}$ latitude and $41^{\circ} 16^{\prime} \mathrm{E}$ longitude and its meteorological (Anonymous, 2001a) and air pollution characteristics (Anonymous, 2001b) are given in Table 1.

Poor quality lignite is used for domestic heating from October to May. The burning of this lignite generate large amount of $\mathrm{SO}_{2}, \mathrm{NO}_{x}$ and $\mathrm{PM}$ that are released into the atmosphere and thus heavy air pollution appears. In addition, the Europe-Turkey-Iran highway passes through the city and vehicles also contribute to air pollution.

\subsection{Sampling sites}

The stone monuments in Erzurum are well-known examples of various civilizations constructed between the 4 th and 17 th centuries. The 6 main historical stone monuments identified with Erzurum

Table 1

The average main climatic and air pollution characteristics in Erzurum (1990-2001)

\begin{tabular}{|c|c|c|c|c|c|c|c|c|c|c|c|c|}
\hline \multirow[t]{2}{*}{ Meteorological parameters } & \multicolumn{12}{|l|}{ Months } \\
\hline & 1 & 2 & 3 & 4 & 5 & 6 & 7 & 8 & 9 & 10 & 11 & 12 \\
\hline Temperature $\left({ }^{\circ} \mathrm{C}\right)$ & -10.1 & -10.6 & -4.7 & 5.1 & 10.5 & 14.6 & 19.0 & 19.0 & 13.5 & 7.3 & -0.4 & -6.9 \\
\hline Precipitation (mm) & 14.7 & 19.4 & 35.9 & 48.3 & 63.9 & 37.8 & 21.9 & 10.8 & 25.2 & 34.3 & 26.3 & 27.9 \\
\hline Moisture (\%) & 77.2 & 77.5 & 77.1 & 67.8 & 63.1 & 59.1 & 53.2 & 50.5 & 53.8 & 64.8 & 73.6 & 80.3 \\
\hline Wind speed $(\mathrm{m} / \mathrm{s})$ & 2.3 & 2.5 & 2.5 & 3.6 & 3.3 & 2.9 & 3.4 & 3.0 & 2.7 & 2.4 & 2.3 & 1.9 \\
\hline \multicolumn{13}{|l|}{ Air pollutants $\left(\mu \mathrm{g} / \mathrm{m}^{3}\right)$} \\
\hline $\mathrm{SO}_{2}$ & 327 & 285 & 230 & 130 & - & - & - & - & - & - & 200 & 285 \\
\hline PM (Particle matter) & 215 & 185 & 135 & 74 & & & & & & & 160 & 200 \\
\hline $\mathrm{NO}_{x}{ }^{a}$ & 142 & 127 & 95 & - & - & - & - & - & - & - & 150 & 159 \\
\hline
\end{tabular}

\footnotetext{
${ }^{\text {a }}$ This parameter was measured between 1984 and 1989, however, no current measurements are available.
} 
were chosen for determining the biodeteriorative effects of the microorganisms on stone decay. Because stone deterioration of the monuments in Erzurum (i.e., on the two minarets of the Double Minarets-Madrasah as seen in Fig. 1) was very intensive, these monuments were restored by the Ministry of Culture and Tourism Republic of Turkey according to their original forms.

The characteristics of the historical buildings are given below:

1) Rustempasa Bazaar (Tashan): The stone monument was built with tufa stone in 1561 during the Ottoman Empire as a Bazaar and is still used as a bazaar for black amber. It has approximately 80 storehouses.

2) The Erzurum Castle Mosque (Erzurum Kalesi Mescidi): It is a historical building built with limestones in 1230 during the Seljukian Empire in the Castle of Erzurum.

3) The Lalapasa Mosque (Lalapasa Camii ): It is a historical building built with tufa stone in 1562 . It has an inner area of $900 \mathrm{~m}^{2}$ and is still used for religious purposes.

4) The Double Minarets-Madrasah (Cifte Minareli Madrese): Built in 1236 with mudurge stone, the Double Minarets is a disused historical building identified with the city and has an inner area of $1536 \mathrm{~m}^{2}$ (Fig. 1).

5) The Great Mosque (Ulu Camii): It is a historical building built in 1180 with tufa (and in places granite) stone. It has an inner area of $2152 \mathrm{~m}^{2}$ and is still used for religious purposes.

6) The Haji Mehmet Fountain (Hacý Mehmet Cesmesi): It is a historical fountain built in 1334 with volcanic (granite) stone. The total height of the fountain is $3.5 \mathrm{~m}$ and specimens were taken from approximately at $3 \mathrm{~m}$.

\subsection{Sample collection}

The stone samples were taken from the external walls of the monuments from $5 \mathrm{~m}$ height of five historical buildings and $3 \mathrm{~m}$ high from the Haji Mehmet Fountain. They were put into the Petri dishes in January and March in Erzurum to prevent contamination stemming from the soil and ground. Sterile devices were used in the sampling and SEM-EDS studies and all of the procedures were done aseptically. The microbiological studies were carried out under sterile conditions.

Two different types of specimens were taken from the stone surface of all the monuments in January and March 2003. During the sampling procedures the daytime and nighttime average temperature was -10 and $-25{ }^{\circ} \mathrm{C}$ in January, -5 and $10{ }^{\circ} \mathrm{C}$ in March.

The first specimen (easily removable flakes) was taken by means of scraping from the stone surface. These samples were used for microbiological incubating and counting. One gram of each sample was squashed with a mortar and weighed. They put into a $50 \mathrm{ml}$ flask with $10 \mathrm{ml}$ sterile physiological solution $(9 \mathrm{~g} / \mathrm{L} \mathrm{NaCl})$, mixed for $15 \mathrm{~min}$ and then serially diluted $\left(10^{-2}, 10^{-3}, \ldots\right.$, etc.) (Vero et al., 1975; Greenberg et al., 1985). The second, non-crumbed (aggregated) stone samples were taken by means of hammer and pliers as very carefully from suitable places on the sampling sites. These specimens used in the microscopic investigation and elemental analyses in the JEOL 6400 SEM-EDS combined system energy dispersive spectrometer.

\subsection{Microbiological examinations}

2.4.1. The counting of aerobic heterotrophic bacteria

In this process, standard plate count agar with nystatin of $50 \mathrm{mg} / \mathrm{L}$ was used. One $\mathrm{ml}$ portions from dilutions were used to make two Petri dishes and $15 \mathrm{ml}$ of culture at $45{ }^{\circ} \mathrm{C}$ were added and incubated at 25 and $37^{\circ} \mathrm{C}$ (Greenberg et al., 1985). At the end of the incubation, the colony-forming unit (CFU) was counted to determine the total culturable aerobic heterotrophic bacteria.

\subsubsection{The counting of fungi and actinomycetes}

In this process, starch-casein agar was used for plate-counting actinomycetes and czapek-dox agar, malt extract agar and peptone dextrose agar for fungi (Greenberg et al., 1985). Respective plates were incubated at 4,20 and $25{ }^{\circ} \mathrm{C}$.

\subsubsection{Identification of microorganisms}

For identification of the fungi, a small portion of each specimen mounted in a few drops of $20 \%$ potassium hydroxide was examined for the presence of characteristic fungal elements and diagnostic mor- 
phology. The samples were cultured on sabouraud dextrose agar containing peptone (10 g), glucose (20 g) and agar $(15 \mathrm{~g})$.The medium was supplemented with chloramphenicol and cycloheximide (50 and 500 $\mathrm{mg} / \mathrm{dl}$ ). The cultures were incubated at $26{ }^{\circ} \mathrm{C}$ and examined twice a week for a total duration of 4 weeks. After that, the isolates were passed through tubes into Petri dishes containing sabouraud dextrose agar and potato dextrose agar. The isolates were examined macroscopically, and microscopically following staining with lactophenol cotton blue. The identification of yeast was based on their macroscopic characteristics as a result of germ tube tests and biochemical tests. The identification of molds was based on their macroscopic characteristics (growth period, colony morphology, production of pigment on the back of the colony), microscopic arrangements (characteristics hyphae formation, types of conidia, sizes and shapes of the sterigmata, hyphae and organs of reproduction) and biochemical tests.

Identification of bacteria was made by the gaschromatography method in the Microbial Identification System (MIS) that is based on bacterial fatty acid methyl ester profiling. First, all samples were incubated in "brain heart infusion broth" to enrich bacterial growth at room temperature $\left(26 \pm 2{ }^{\circ} \mathrm{C}\right)$ for $8 \mathrm{~h}$. After incubating each cultures, $1 \mathrm{ml}$ suspension was transferred to $5 \%$ blood agar and "trypticase soy broth agar (TSBA)" media and incubated at room temperature $\left(26 \pm 2{ }^{\circ} \mathrm{C}\right)$ for $24 \mathrm{~h}$ to be identification by MIS. In the identification by MIS, the subcultures of bacteria on the $5 \%$ blood agar and TSBA medium were used. Cultures were extracted by saponification, and methylation. The extracts were subsequently washed with bases. The extractions were performed in one batch simultaneously, in order to reduce the differences caused by environmental conditions. The saponification reagent consisted of sodium hydroxide, methanol (HPLC grade), and deionized distilled water. Methylation reagent was $6 \mathrm{~N}$ hydrochloric acid in methanol (HPLC grade). Ingredients of the extraction solvent was hexane (HPLC grade), methyl-tert butyl ether (MTBE) (HPLC grade). The base washing step was carried out using diluted $\mathrm{NaOH}$. After the wash step, the extract was transferred to a special gas chromatography sample vial containing anhydrous sodium sulfate according to the manufacturer's instructions. Whole-cell fatty acids were extracted and analyzed as methyl ester derivatives. The fatty acid profiles were analyzed using "The Sherlock Microbial Identification System 7673". The Sherlock MIS chromatographic unit consists of a Hewlett-Packard 6890 Gas Chromatograph, a 7673 Automatic Sampler (with injector, controller, and tray), and Hewlett-Packard Chemstation software. The fatty acids extracted from the microorganisms were automatically quantified and identified by MIS and the fatty acid profiles were determined and compared to a library of reference organisms in the database to identify our bacteria.

\subsection{SEM micrographic examinations}

Specimens taken from the historical buildings were broken into small pieces under aseptic conditions. Then, conductivity of external surfaces of the stone samples was provided by sputtering with $\mathrm{Au}-\mathrm{Pd}$ target using a sputter-coater and thus the samples were ready to be examined as natural form in JEOL 6400 SEMEDS combined system energy dispersive spectrometer. After the samples coated in a nanometer degree were attached in the holder of SEM, they were placed into the vacuum chamber to photograph and elemental analysis (EDS). Secondary electron images and energy dispersive spectra of external surfaces of the stone samples were obtained at 10/25/30 and $25 \mathrm{keV}$ energy level, respectively. SEM micrographs were taken between 50-7000 $\times$ magnifications.

\section{Results and discussions}

\subsection{Interaction between air pollution and biodeterioration}

Air pollution due to domestic heating and transportation has increased the atmospheric concentration of inorganic and organic compounds in the form of gases, aerosols or particulate matter. The concentrations of air pollutants such as $\mathrm{SO}_{2}, \mathrm{NO}_{x}$ and particles released into the atmosphere as a result of the burning of the fossil fuels are given in Table 1 .

These parameters were measured during the winter period from November to April and were not measured in the summer period (May-September) because there was no considerable air pollution in this period. Since no major industrial plant was in 


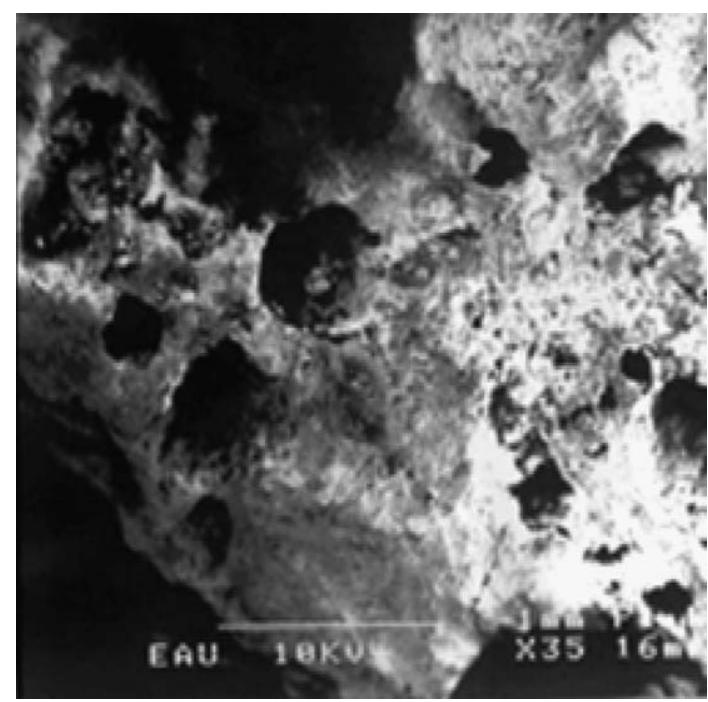

Fig. 2. The way of deterioration on the volcanic stone surface at the Haji Mehmet Fountain.

use in Erzurum, sulfur dioxide concentration stemming from transportation is approximately $10 \mu \mathrm{g} / \mathrm{m}^{3}$ in summer (Anonymous, 2001b). Table 1 shows that the average monthly temperature is below $0{ }^{\circ} \mathrm{C}$ during five months of the year, and the snowfall is most intense during this period. While the average wind speed is $3.1 \mathrm{~m} / \mathrm{s}$ during the summer season, this parameter is $2.2 \mathrm{~m} / \mathrm{s}$ in the winter. This situation causes difficulty for dispersion of the air pollutants during the winter. Since the relative moisture is high during the winter period, building stones remain damp, which provides a suitable condition for the settlement of air pollutants and microorganisms on stone surfaces. Different elemental compositions of the stones, air pollutants and moisture provide a suitable surrounding for the microorganisms to develop by obtaining energy from them. Therefore, the developing microorganisms on stone surfaces deteriorate the stones in time by secreting enzymes and activating other metabolic activities by providing a suitable medium for their growth on the stone pores and surfaces (Warscheid and Braams, 2000; Dornieden et al., 2000). The deteriorative effect can be seen in Fig. 2. Sulfur dioxide is one of the major gaseous components of polluted atmospheres in urban areas. Because oxidation of sulfur dioxide results in the formation of sulfuric acid, there is a strong correlation between the sulfation of limestones and the atmo- spheric concentration of sulfur dioxide. Sulfuric acid attacks limestones resulting from in the formation of gypsum. During the crystallization of gypsum, airborne organic pollutants, carbonaceous particles, dust, etc. are accumulated at the surface of buildings and trapped in the mineral matrix. Accumulations of pollutant particles on the stone surfaces are seen in Fig. 3. This results in the formation of a hard, grey to black crust. This crust enriches the substratum and anthropogenic compounds may influence, to a great extent, the colonization and growth pattern of microorganisms in stones located in polluted environments (Saiz-Jimenez, 1997).

\subsection{Interaction between weathering agents, elemental composition of stones and biodeterioration}

As soon as a stone piece is used in stone monuments, it comes into contact with a variety of physical, chemical and biological agents that alter it. In situ deterioration of stone in monuments is a combined process caused by physical, chemical and biological factors. The relative importance of each factor varies according to topoclimatic environmental conditions, the stone type, its preservation state and its location on the monument. The impact of physical and chemical factors determined by exposure conditions such as moisture, atmospheric and anthropogenic influences, and the nature of the stone itself need to be considered during any preliminary data elaboration and object anamnesis. Mineralogy controls attack of stones by water or bacteria (Papida et al., 2000). On the other

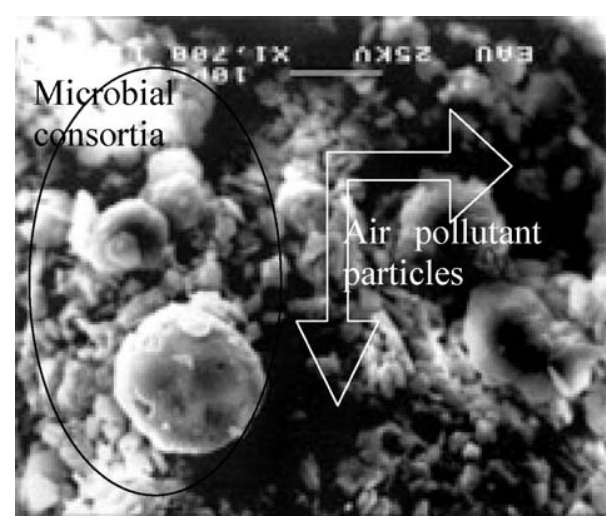

Fig. 3. The microbial consortia (with air pollutant particles) dwelling in tufa stone pores at the Great Mosque. 
hand, pore size, distribution and specific surface area together with the capillarity of a stone control the mechanical degradation caused by water, salts, and bacteria. Understanding the complex interactions between these microorganisms and their mineral substrate is a topic of current interest, since it may shed light on the bioweathering of stone monuments. For these reasons, the stone type, the mineralogical composition and the appearance of the microorganisms on the stone surfaces were determined to access the biological contribution to stone decay correlated with the type of stone material and exposure conditions for the monuments, including wind, sunlight and temperature, as well as rain, snow and moisture. These agents will induce both physical and chemical weathering processes. The first affect the stability of the rock matrix, while the second act through chemical corrosion of the stone-forming minerals, such as oxidation and hydration reactions as well as dissolution of carbonates and solubilization of some elements from silicate bearing minerals(Warscheid and Braams, 2000).

Biodeterioration of exposed stone is primarily dependent on the availability of water and nutrients. Microorganisms are able to obtain several elements that they need for their metabolism (e.g., calcium, aluminium, silicon, iron and potassium) from the limestone by biosolubilization. This biosolubilization process generally involves the production of various organic and inorganic acids by algae, lichens, fungi and bacteria. As seen in Fig. 2, in addition to the other deteriorative agents such as mechanical and chemical destructive factors, the release of aggressive acids is one of the best known biogeochemical destructive mechanisms at rock surfaces and it occurs through the leaching of rock-binding materials with the con-

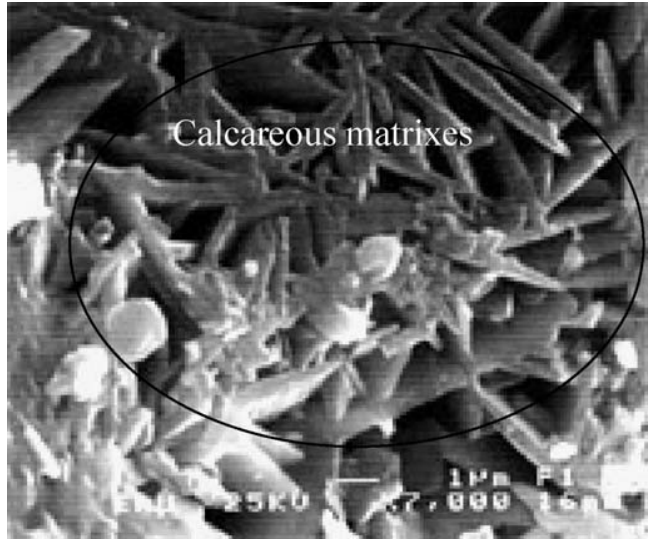

Fig. 4. The calcareous matrixes of stone surface at the Lalapasa Mosque.

sequent weakening of the crystal structure (Videla et al., 2000). For this reason, two different types of specimens were taken from the stone surface of all the monuments. The first specimen (easily removable flakes) were used for microbiological incubating and counting because these materials seems to be subjected to a dense microbial attack. Therefore they have more microorganisms than the second (aggregated) one. The second, non-crumbed (aggregated) stone samples were used in SEM micrographic examinations and elemental analyses for smooth and durable surface area against electron bombardment.

Fig. 2 shows the type of deterioration on stone surfaces at the Haji Mehmet Fountain and like the other stone monuments in Erzurum. The microorganisms on the stone surfaces could not be seen because of low magnification, and macro biodeteriorative organisms such as mosses and lichens were not dominant because of the extreme cold weather in wintertime.

Table 2

The elemental analyses of the stone samples taken from the historical building in January 2003

\begin{tabular}{|c|c|c|c|c|c|c|c|c|c|c|c|c|c|c|}
\hline \multirow[t]{2}{*}{ The monument } & \multirow[t]{2}{*}{ Stone type } & \multicolumn{13}{|c|}{ The elemental analyses of the stone samples (wt.\%) } \\
\hline & & $\mathrm{Si}$ & $\mathrm{Al}$ & $\mathrm{Ca}$ & $\mathrm{K}$ & $\mathrm{Ti}$ & $\mathrm{Mg}$ & $\mathrm{Zn}$ & $\mathrm{S}$ & $\mathrm{Fe}$ & $\mathrm{Na}$ & $\mathrm{Mn}$ & $\mathrm{Nb}$ & Others $^{\mathrm{a}}$ \\
\hline 1 & Tufa & 5.48 & 3.77 & 23.49 & 0.85 & 0.38 & 0.34 & 2.41 & 12.10 & 1.681 & 1.37 & - & 7.71 & 40.42 \\
\hline 2 & Limestone & 25.48 & 9.83 & 4.88 & 2.40 & - & 2.79 & 5.17 & 0.38 & - & - & 0.27 & 4.04 & 44.76 \\
\hline 3 & Tufa & 5.03 & 36.27 & 21.13 & 1.90 & - & 0.12 & - & - & - & 1.12 & 1.92 & 8.02 & 24.49 \\
\hline 4 & Mudurge & 31.82 & 5.95 & 2.41 & 0.71 & - & 1.99 & 3.18 & 0.90 & - & - & 0.39 & 4.51 & 48.14 \\
\hline 5 & Tufa & 27.77 & 10.54 & 1.74 & 1.42 & - & 2.14 & 0.22 & 4.08 & - & 1.70 & 0.39 & - & 50.00 \\
\hline 6 & Granite & 25.26 & 10.02 & 4.94 & 1.52 & 0.84 & 1.98 & 4.65 & 0.59 & 4.45 & - & - & - & 45.75 \\
\hline
\end{tabular}

${ }^{a}$ These elements are carbon, oxygen and small amounts of non-detectable elements. 


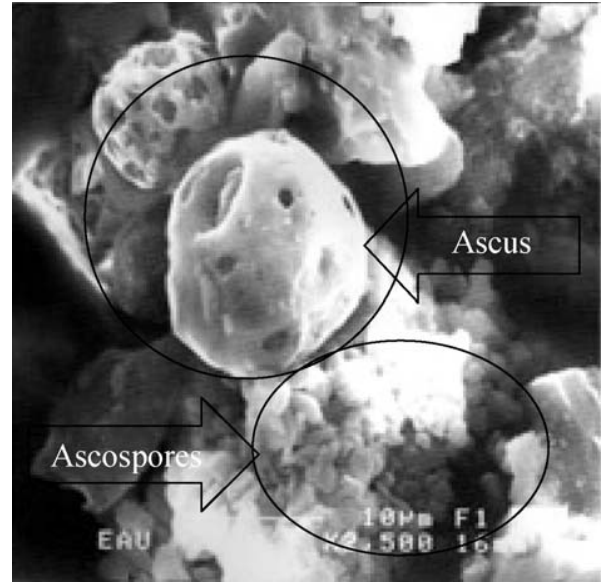

Fig. 5. The microscopic ascus and thousand of ascospores belonging to microscopic ascomycetes inner pore surfaces at the Erzurum Castle Mosque.

The elemental analyses of the stones on historical buildings examined by means of SEM-EDS are shown in Table 2. The secondary electron images (SEI) of the stone-surfaces of the historical buildings are shown in Figs. 2-8.

SEM observations showed that a heterotrophic microflora, composed of fungi, actinomycetes and bacteria dominates the stone surfaces in the historical buildings at all the stone monuments during the winter months in Erzurum. These findings fit into the hypothesis that heterotrophic microflora could often be the first colonisers of stone materials exposed to the atmospheric pollution, because of

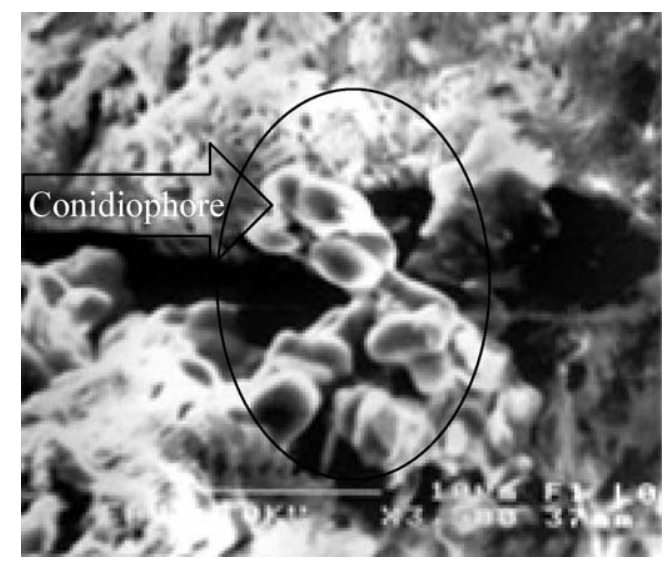

Fig. 6. The conidiophore of Penicillium sp. at the Double Minaret Madrasah.

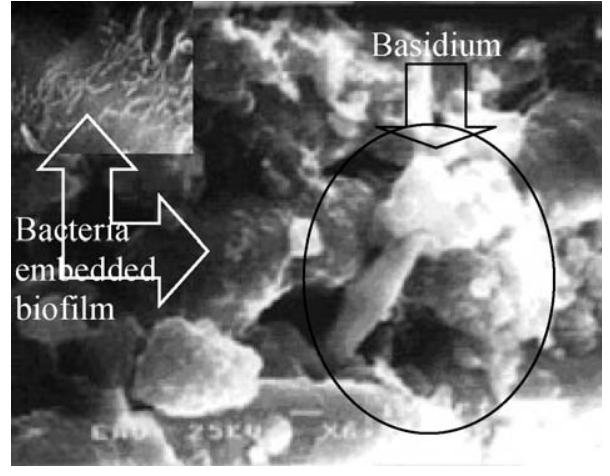

Fig. 7. The way of deterioration: the microbial biofilm and the basidiomycetes on mudurge stone surface at the Double Minaret Madrasah. The surface of salient parts was covered by bacteria embedded jelly-microbial biofilm and the bacteria, probably Virgibacillus $\mathrm{sp}$.

their ability to grow utilizing organic pollutants (Saiz-Jimenez, 1997; Zanardini et al., 2000). This evidently confirmed that the heterotrophic microflora formed on dominant flora of the stone materials exposed to atmospheric pollution eliminated the autotrophic flora due to extreme climatic conditions in winter.

Urban air pollutants contain aliphatic and aromatic hydrocarbons. It is demonstrated that the black crusts coating buildings in European cities where the air pollution is high are rich in both aliphatic and polycyclic aromatic hydrocarbons (Saiz-Jimenez, 1993; Ascaso et al., 2002). These chemicals were found to be trapped in the mineral matrices of the buildings. An investigation of the coexistence of dif-

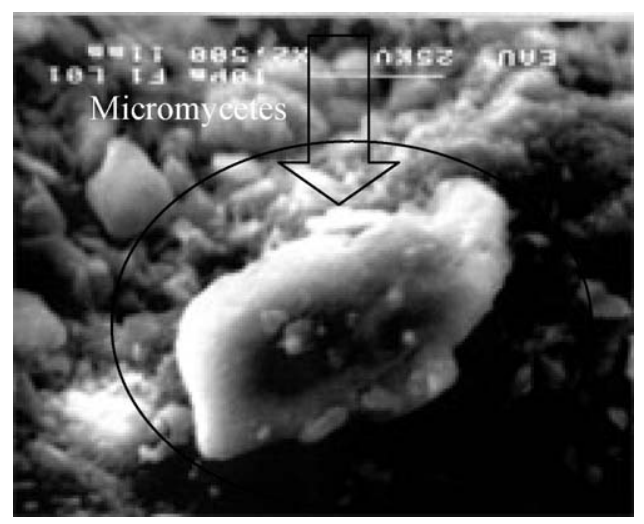

Fig. 8. The micromycetes dwelling on tufa stone surfaces at the Rustempasa Bazaar. 
ferent particle forms of biogenic calcium carbonate deposits within the microbial biofilm was investigated by Gerdes et al. (1994), who showed that aragonite accumulation occurs due to biologically induced physiochemical changes in the microenvironment of the interface. Hydration-dehydration cycles might exert a clear biogeophysical effect on the stone. The antidesiccant role of EPS (extracellular polysaccharides) favors water absorption and thus the hydration-dehydration cycling of these organisms as well as that of any clay minerals present. (Ascaso et al., 2002).

Table 2 shows $\mathrm{Si}, \mathrm{Al}, \mathrm{Ca}, \mathrm{K}$, and $\mathrm{Mg}$ present in all samples. These elements constitute the main components of the stones. $\mathrm{Si}, \mathrm{Al}, \mathrm{Ca}, \mathrm{K}$ and $\mathrm{Mg}$ are in the range of about 5-32, 3-37, 1.5-23.5, 0.5-2.50 and $0.1-3 \%$, respectively. In addition, significant quantities of $\mathrm{Zn}, \mathrm{S}, \mathrm{Mn}$ and $\mathrm{Nb}$, small quantities of $\mathrm{Na}, \mathrm{Fe}$ and $\mathrm{Ti}$ are present some stones. Among these elements $\mathrm{Ca}, \mathrm{K}, \mathrm{Mg}, \mathrm{Zn}, \mathrm{S}, \mathrm{Mn}, \mathrm{Na}$ and $\mathrm{Fe}$ existence are desirable because they contribute to the development of the microorganisms on stone surfaces and exist in the compounds of stones on historical buildings (SaizJimenez, 1997; Tomaselli et al., 2000; Warscheid and Braams, 2000).

The stones in all of the monuments contain a significant amount of calcium. Calcium can be leached from the calcite crystal lattice by an ion exchange mechanism in which ammonium and magnesium ions are involved. The liberation of ionic sodium, potassium, calcium, magnesium and aluminium could be used as an indicator of deterioration (Videla et al., 2000). The calcareous matrixes of stone surface at the Lalapasa Mosque are shown in Fig. 4. The presence of exchangeable calcium in the stone, such as calcareous sandstones, concrete or lime mortars, plays a role the buffering of biogenic metabolic products producing a constant suitable $\mathrm{pH}$-milieu for the growth of bacteria (Altieri and Ricci, 1997). The Lalapasa Mosque consists of a dense calcareous matrix allowing mainly for a superficial microbial contamination. Nevertheless, the material seems to be subject to fungal attack (Altieri and Ricci, 1997; Warscheid and Braams, 2000). In Figs. 5-7, it is seen that several fungal growth especially reproductive forms on the stone surfaces owing to restriction of cold weather when the nighttime temperature was about $-25{ }^{\circ} \mathrm{C}$ for ten days (Anonymous, 2001a).
The stones of the first and sixth monuments have significant amounts of iron and the 2nd, 3rd, 4th and 5th monuments have manganese. As seen from Fig. 3, the stone surfaces contain pollutant particles. Chemoorganotrophic bacteria and fungi are often present in the surface biofilms on the stones and use organic substrates such as hydrogen, carbon, and energy source. They commonly excrete complexing biocorrosive organic acid (i.e., oxalic, oxaloacetic, citric, gluconic, glyoxalic, fumaric) or weaken the mineral lattice by the oxidation of metal cations such as $\mathrm{Fe}^{+2}$, or $\mathrm{Mn}^{+2}$ (Warscheid et al., 1993; Warscheid and Braams, 2000). These acids are efficient for rather slowly-solving cations such as $\mathrm{Ca}, \mathrm{Al}, \mathrm{Si}, \mathrm{Fe}, \mathrm{Mn}$ and $\mathrm{Mg}$ from minerals forming stable complexes (Eckhardt, 1985; Lewis et al., 1988 and Warscheid and Braams, 2000). It has been shown that biogenic organic acids are considerably more effective in mineral mobilization than inorganic acids and are considered as one of the major damaging agents biogeochemical destructive mechanisms at rock surfaces (Saiz-Jimenez, 1997; Warscheid and Braams, 2000 ), with leaching of rock binding materials and consequent weakening of the crystal structure (SaizJimenez, 1997). The result of this type of biodeterioration is the physical and mechanical breakdown of the stone. The isolation of biocorrosive organic acid excreted by microorganisms on all of the stone monuments indicated that these microorganisms have accelerating effects on the biodeterioration under heavy air pollution observed during the continental-cold climatic conditions in Erzurum. Since deterioration of external walls of the stone monuments caused by microorganisms and the other deteriorative factors such as unfavoured climatic conditions, these monuments were erased by deteriorative agents. For example, the deteriorative effect can be clearly seen in Figs. 1 and 2. For this reason, the Rustempasa Bazaar, the Lalapasa Mosque, the Double Minarets-Madrasah and the Great Mosque were restored with the original stones by the Ministry of Culture and Tourism Republic of Turkey according to the original forms.

\subsection{Microbial activity in the extreme cold climatic conditions}

During the sampling procedures the daytime and nighttime temperature average was -10 and $-25{ }^{\circ} \mathrm{C}$ 
Table 3

The species and groups of microorganisms isolated from stone surfaces

\begin{tabular}{|c|c|c|c|c|c|c|}
\hline \multirow{2}{*}{$\begin{array}{l}\text { The species and groups } \\
\text { of microorganism }\end{array}$} & \multicolumn{6}{|c|}{ The monuments ${ }^{\mathrm{a}}$} \\
\hline & 1 & 2 & 3 & 4 & 5 & 6 \\
\hline \multicolumn{7}{|l|}{ Fungi } \\
\hline Cladosporium orchidis & + & - & + & - & + & - \\
\hline Paecilomyces lilacinus & - & - & - & + & - & + \\
\hline Penicillium frequentans & + & + & + & + & + & - \\
\hline Embellicia hyacinthi & + & + & - & + & - & + \\
\hline Alternaria alternata & - & + & + & - & + & - \\
\hline Phoma sp. & - & + & - & - & + & - \\
\hline
\end{tabular}

\section{Bacteria}

Bacillus subtilis

Bacillus licheniformis

Bacillus lentimorbus

Bacillus cereus

Bacillus mycoides

Bacillus thuringiensis kenyae

Bacillus thuringiensis sotto

Bacillus agri

Bacillus coagulans

Brevibacillus laterosporus

Paenibacillus apiarius

Paenibacillus larvae-pulvifaciens

Virgibacillus pantothenticus

Arconobacterium haemolyticum

Streptoverticillium reticulum but fungi and actinomycetes live on stone surfaces under extreme cold climatic conditions because they generate many more spores than bacteria. The species of bacteria in Table 3 are mostly spore-forming bacteria. It is well known, in general, the reproductive (generative) forms of microorganisms (as spore) were more resistant than vegetative forms. For this reason, the microorganism formed as spores usually covered all of the stone surfaces even in the extreme cold conditions in January. Chemoorganotrophic bacteria, fungi and coryneform actinomycetes are often present in surface biofilms on stones, which allow them to withstand abrupt changes in atmospheric conditions, as well as food shortages (Warscheid and Braams, 2000). It is estimated that the vegetative forms of the microorganisms living on stone surfaces, especially bacteria and actinomycetes, protect themselves from the limiting effects of extreme cold-climatic conditions in Erzurum trough surface-covering biofilm as seen in Fig. 7. For this reason, it is supposed that these microorganisms have facultative aerobic metabolism, because surface covering biofilm diminished in open-air conditions.

The colony forming units of all microorganisms in Table 4 are fewer than the number of fungi, actinomycetes and bacteria in the SEM images. This occurrence is attributed to all of the vegetative and reproductive parts of the microorganisms on stone surfaces are not culturable, except for a very few. On the other hand, the size of vegetative and generative organs (forms) of the microorganisms observed by the SEM images on stone surfaces are smaller than the cultural medium, soil and plant surfaces because the stone is a poorer enrichment media than the cultural medium for the microorganisms (Dornieden et al., 2000 and van der Gast et al., 2001). At the same time, when Table 4 is examined, it is observed that the

Table 4

The number of microorganisms in the stone samples of the monuments in January and March 2003 (as CFU/1 g of the sample)

\begin{tabular}{|c|c|c|c|c|c|c|}
\hline \multirow[t]{2}{*}{ The monuments } & \multicolumn{2}{|l|}{ Fungi } & \multicolumn{2}{|c|}{ Aerobic-heterotrophic bacteria } & \multicolumn{2}{|c|}{ Actinomycetes } \\
\hline & January & March & January & March & January & March \\
\hline Rustempasa Bazaar & 7300 & 11700 & 3100 & 6700 & 650 & 920 \\
\hline The Erzurum Castle Mosque & 370 & 0 & 920 & 7700 & 590 & 480 \\
\hline Lalapasa Mosque & 8200 & 9400 & 4700 & 4000 & 2600 & 5700 \\
\hline The Double Minarets-M. & 710 & 2730 & 350 & 510 & 70 & 970 \\
\hline The Great Mosque & 3200 & 2700 & 3700 & 850 & 930 & 2800 \\
\hline The H. Mehmet Fountain & 2230 & 4200 & 310 & 2320 & 0 & 820 \\
\hline
\end{tabular}


fungi and aerobic heterotrophic bacteria commonly developed on the stones of all the historical buildings. Actinomycetes are smaller than fungi and aerobic heterotrophic bacteria.

The deteriorating effect of chemolithotrophic bacteria will probably be minimal under severe building conditions, since they are very sensitive to desiccation and grow slowly in moderate temperatures (Sand and Bock, 1991; Warscheid and Braams, 2000). It is seen that all of the outdoor stone surfaces in the stone monuments were covered completely bacteria embedded in microbial biofilm (as seen in Fig. 7), vegetative and generative organs of fungi and actinomycetes (as seen in Figs. 5-8) under extreme cold conditions at $-10{ }^{\circ} \mathrm{C}$ daytime and $-25{ }^{\circ} \mathrm{C}$ at night in January. This occurrence confirmed that all of the microorganisms may have a significant role to play in the decay of stones under cold environments like Erzurum because they may have developed new mutants for adaptation to extreme cold conditions.

\subsection{Isolated microorganisms from the stone monuments.}

In Table 3, the following species and genera of microorganisms were identified on the stone surfaces and pores of the monuments in January 2003. Of 21 isolates, 15 species from 6 bacterium genera and 5 species from 5 fungi genera plus 1 fungi genera were identified from the stone surfaces of the stone monuments in Erzurum. The CFU (colony forming unit) per $1 \mathrm{~g}$ in the samples taken from all of the stone monuments at 5 (3) $\mathrm{m}$ above ground are shown in Table 4. It is also discussed above that these microorganisms are largely spore forming microorganisms because the microbial activity was restricted by extreme cold conditions and the reproductive forms of microorganisms were more resistant than the vegetative forms.

It is determined in many researches that various types of fungi, bacteria and actinomycetes act on the biodeterioration processes (Praderio et al., 1993; Warscheid, 1996; Saiz-Jimenez, 1997; Zanardini et al., 2000; Warscheid and Braams, 2000; Herrera et al., 2004). Among these microorganisms the genera of fungi such as Fusarium sp., Penicillium sp., Aspergillus sp., Mucor sp., Ulocladium sp., Botriotrichum sp., Engyodontium sp. and the genera of bacteria such as Bacillus sp., Thiobacillus sp., Pseudomonas sp.,
Nocardia sp., Nitrosomonas sp., Nitrobacter sp. use hydrocarbons, sulfur and nitrogen compounds stemming from air pollution and act on the biodeterioration of stone. It was isolated some of these microorganisms. They have utilized elemental components of the monuments such as $\mathrm{Ca}, \mathrm{K}, \mathrm{Mg}, \mathrm{Zn}, \mathrm{S}, \mathrm{Mn}, \mathrm{Na}, \mathrm{Fe}$ and airborne organic compounds stemming from incomplete combustion of fossil fuels that settled on the stone surface, and they have accelerating effects on the biodeterioration of stone under air pollutants and continental-cold climatic region in Erzurum. It is proposed that some of the identified microorganism species are special for the accelerating effects of the microorganisms on biodeterioration of stone monuments under air pollution and continental-cold climatic conditions in Erzurum: Paecilomyces lilacinus, Bacillus thuringiensis kenyae, Bacillus thuringiensis sotto, Bacillus agri, Brevibacillus laterosporus, Paenibacillus apiarius, Paenibacillus larvae-pulvifaciens, Virgibacillus pantothenticus, Arconobacterium haemolyticum, Streptoverticillium reticulum.

\section{Conclusions}

Photosynthetic micro/macro-organisms such as mosses and lichens were not dominant because the extreme cold weather in wintertime restricted to photosynthesis in Erzurum. Heterotrophic microflora, composed of fungi, actinomycetes and bacteria dominates the stone surfaces in all of the stone monuments during the winter months.

Although the deterioration of stone monuments in tropical regions due to the action of biodeteriogens has long been recognized, only this research brings up that the microorganisms can play a significant role on biodeterioration of stone monuments under extreme cold climatic region. When Table 4 is evaluated and the results are compared with the other researches, it is seen that there are a few aerobic heterotrophic bacteria as colony-forming units in the other sides (researches) but the other main microbial flora (fungi and actinomycetes) are similar with moderate climatic regions (Praderio et al., 1993 and Zanardini et al., 2000). However, Erzurum is the coldest city with average monthly temperatures below zero during five months of the year and that microbial metabolism of the dwelling microorganisms of stone surfaces can be 
restricted by extreme cold weather. The small amount of aerobic heterotrophic bacteria may be due to the extreme cold weather, but the other microbial flora such as fungi and actinomycetes may develop like a normal population in moderate climatic regions. This occurrence attributed to the fungi, actinomycetes and even bacteria may have developed new mutants for adaptation to extreme cold climatic conditions in Erzurum.

\section{Acknowledgements}

We would like to thank Professor Dr. Ihsan Efeoglu and research assistant Ferhat Bulbul from the Department of Mechanical Engineering at Ataturk University for special efforts during the SEM-EDS analyses.

\section{References}

Altieri A, Ricci S. Calcium uptake in mosses and its role in stone biodeterioration. Int Biodeterior Biodegrad 1997;40:201-4.

Anonymous. The data of Turkish State Meteorological Service. Ankara; 2001a.

Anonymous. The data of Environmental Problem Research Center. Atatürk University, Erzurum; $2001 \mathrm{~b}$.

Ascaso C, Wierzchos J, Souza-Egipsy V, de los Ríos A, Delgado J, Rodrigues J. In situ evaluation of the biodeteriorating action of microorganisms and the effects of biocides on carbonate rock of the Jeronimos Monastery (Lisbon). Int Biodeterior Biodegrad 2002;49:1-12.

Dornieden Th, Gorbushina AA, Krumbein WE. Biodecay of cultural heritage as a space/time-related ecological situation-an evaluation of series of studies. Int Biodeterior Biodegrad 2000;6:261-70.

Eckhardt FEW. Solubilization, transport, and deposition of mineral cations by microorganisms-efficient rock weathering agents. In: Drever JI, editor. The chemistry of weathering. Dordrecht: D. Reidel Publ. Comp. Ltd.; 1985. p. 161-73.

Gerdes G, Denajtschik-Piewak K, Riege H, Taher AG, Krumbein WE, Reineck HE. Structural diversity of biogenic carbonate particles in microbial mats. Sedimentology 1994;41: $1273-94$.

Greenberg AE, Trussell RH, Clesceri LS. Standard methods for the examination of water and wastewater, Sixteenth edition. Washington: American Public Health Association; 1985. p. 860-864, 864-866 and 981-984.

Herrera LH, Arroyave C, Guiamet P, de Saravia SG, Videla H. Biodeterioration of peridotite and other constructional materials in a building of the Colombian Cultural Heritage. Int Biodeterior Biodegrad 2004;53:135-41.
Kumar R, Kumar AV. In: Agnew Neville, editor. Biodeterioration of stone in tropical environments. USA: J. Paul Getty Trust; 1999(0-89236-550-1). p. 1-2.

Lewis FJ, May E, Bravery AF. Metabolic activities of bacteria isolated from building stone and their relationship to stone decay. In: Houghton DR, Smith RN, Eggins HOWBiodeterioration. London, New York: Elsevier Applied Science; 1988. p. $107-12$.

Papida S, Murphy W, May E. Enhancement of physical weathering of building stones by microbial populations. Int Biodeterior Biodegrad 2000;46:305-17.

Praderio G, Schiraldi A, Sorlini C, Stassi A, Zanardini E. Microbiological and calorimetric investigation on degraded marbles from the Ca' D'Oro facade (Venice). Thermochim Acta 1993;227:205-13.

Saiz-Jimenez C. Deposition of airborne organic pollutants on historic buildings. Atmos Environ 1993;27b:77-85.

Saiz-Jimenez C. Biodeterioration vs biodeterioration: the role of microorganisms in the removal of pollutants deposited onto historic buildings. Int Biodeterior Biodegrad 1997;40: 225-32.

Sand W, Bock E. Biodeterioration of mineral materials by microorganisms-biogenic sulfuric and nitric acid corrosion of concrete and natural stone. Geomicrobiol J 1991;9:129-38.

Tecer L, Cerit O. The effects of air pollution on carbonate stone monuments in urban areas (Sivas, Turkey). Fresenius Environ Bull 2002;11:505-9.

Tomaselli L, Lementi G, Bosco M, Tiano P. Biodiversity of photosynthetic micro-organisms dwelling on stone monuments. Int Biodeterior Biodegrad 2000;6:251-8.

van der Gast CJ, Knowles CJ, Wright MA, Thompson IP. Identification and characterisation of bacterial populations of an in-use metal-working fluid by phenotypic and genotypic methodology. Int Biodeterior Biodegrad 2001;47:113-23.

Vero LB, Bianchi R, Sila MM, Tiano P. Proposal of a method of investigation for the study of the presence of bacteria in exposed works of art in stone. Conservation of stone I International symposium, June 19-21, Bologna; 1975. p. 257-66.

Videla HA, Guiamet PS, Gomez de Saravia S. Biodeterioration of Mayan archaeological sites in the Yucatan Peninsula, Mexico. Int Biodeterior Biodegrad 2000;46:335-41.

Warscheid Th. Impacts of microbial biofilms in the deterioration of inorganic building materials and their relevance for the conservation practice. Internationale Zeitschrift für Bauinstandsetzen 1996;26:493-504.

Warscheid Th, Braams J. Biodeteriration of stone: a review. Int Biodeterior Biodegrad 2000;46:343-63.

Warscheid Th, Becker Th, Braams J, Brüggerhoff S, Gehrmann C, Krumbein WE, et al. Studies on the temporal development of microbial infection of different types of sedimentary rocks and its effect on the alteration of the physico-chemical properties in building materials. In: Thiel M-JConservation of stone and other materials. London: E and FN Spon; 1993. p. $303-10$.

Zanardini E, Abbruscato P, Ghedini N, Realini M, Sorlini C. Influence of atmospheric pollutants on biodeterioration of stone. Int Biodeterior Biodegrad 2000;45:35-42. 